Biota: Jurnal Ilmiah Ilmu-Ilmu Hayati, Vol. 6 (2): 129-137, Juni 2021

p-ISSN 2527-3221, e-ISSN 2527-323X, https://ojs.uajy.ac.id/index.php/biota

DOI: $10.24002 /$ biota.v6i2.4278

\title{
Utilization of Used Cardboard and Vegetable Waste as Growth Media for White Oyster Mushroom (Pleurotus ostreatus)
}

\author{
Jovita Lavenia ${ }^{1}$, Aniek Prasetyaningsih ${ }^{1}$, Catarina Aprilia Ariestanti ${ }^{{ }^{*}}$ \\ ${ }^{1}$ Biology Study Program, Faculty of Biotechnology, Duta Wacana Christian University \\ Dr. Wahidin Sudirohusodo Street number 5-25, Gondokusuman, Yogyakarta City, D.I. Yogyakarta, Indonesia \\ Email: catarina.ariestanti@staff.ukdw.ac.id \\ *Penulis Korespondensi
}

\begin{abstract}
White oyster mushroom (Pleurotus ostreatus) is a highly nutritious food with simple cultivation process using sawdust as its main substrate. Nowadays, availability of sawdust become a problem for some mushroom farmers. Cardboard and vegetable wastes are easily found and difficult to maintain. Based on their characteristics, those wastes can be used as mushroom growth media. This study aims to determine the effect of cardboard and vegetable waste on mushroom growth and the best media composition to obtain maximum productivity. Those wastes are used as the main substrate in eleven composition variations with complete randomized design (CRD) analysis method using One-Way ANOVA and simple linear regression statistical test. The results showed, variations in media composition affect the condition of the media which then influence the growth of $P$. ostreatus. Maximum productivity was found in media composition XI with mycelium growth rate up to 3.91 cm/day, media IX with the biological efficiency up to $45.38 \%$, and media $X$ with the highest total yield up to 97.28 grams. From this study it can be concluded that cardboard and vegetable waste can be an alternative growth substrate for $P$. ostreatus in urban areas with a maximum concentration of vegetable waste no more than $30 \%$ by weight of the media used.
\end{abstract}

Keywords: Pleurotus ostreatus, Biological Efficiency, Yield, Cardboard, Vegetable Waste.

Diterima: 22 Maret 2021, disetujui: 20 Mei 2021

\section{Introduction}

White oyster mushrooms (Pleurotus ostreatus) is a popular edible mushroom from phylum Basidiomycota (Stamets \& Chilton, 1983) with high nutritional value, contain of protein consisting of 9 essential amino acids (10.5-30.4\%), fat (1.6-2.2\%), carbohydrates (57.6-81.8\%), and crude fiber (7.5-8.7\%) (Hakiki et al., 2013). These values with its health benefit played an important role to the increasing demand for the white oyster mushroom production. During the cultivation process, mushroom farmers normally use wood dust (sawdust) as the main substrate for growing media. Generally sawdust originated from Paraserianthes falcataria wood and it can accelerate the growth of mushroom because of its high cellulose, hemicellulose and lignin content (Hariadi et al., 2013). The availability of sawdust for oyster mushroom cultivation has become a problem for some mushroom farmers.
In urban areas, especially in big city like Yogyakarta, Indonesia, solid waste such as used cardboard and vegetable waste from the market is rarely being reprocessed. Based on observations, those solid wastes are often thrown away and there was no effort to utilize it optimally. Cardboard is a basic packaging material that is rich in lignocellulosic residues (Kulshreshtha et al., 2013). Cellulose is needed as a carbon source to support the growth of oyster mushrooms, while vegetable waste is still rich in nitrogen $(\mathrm{N})$ content that is able to fulfill the needs of mushroom for the $\mathrm{N}$ elements (Kadam et al., 2008).

Recycling of used cardboard and market vegetable wastes are one of the ways to utilize organic waste to product of high nutritional food such as through the cultivation of white oyster mushrooms (Singh \& Singh, 2012). Several studies revealed the successful use of used cardboard and vegetable waste as a medium in the cultivation of $P$. ostreatus in urban areas. Owaid et al. (2015) and Mandeel et al. (2005) proved the successful utilization of cardboard waste as a growing media for $P$. 
ostreatus as it can be seen from the value of biological efficiency (BE) were $68.1 \%$ and $117.5 \%$ respectively, with harvest yield were $72.7 \mathrm{~g}$ and $395.9 \mathrm{~g}$ respectively. Singh \& Singh (2014) successfully demonstrated the success of adding 30\% vegetable waste in the form of radish leaves in the growing media with $\mathrm{BE}$ value was $99 \%$.

Yet there were no studies reported to use the combination of used cardboard with market vegetable waste as the main substrate in mushroom growing media. Therefore, this research is expected to be an alternative solution in increasing food security and community empowerment in urban areas. This study aims to determine the effect of cardboard and vegetable wastes on mushroom growth and determine the composition of the best alternative media that are capable to produce maximum productivity of $P$. ostreatus.

\section{Research Methods}

\section{Materials}

White oyster mushroom (P. ostreatus) seeds (F3) was purchased from a mushroom production house (Yogyakarta, ID). Used cardboard was obtained from CV. Kurniatama AC (Yogyakarta, ID). Market vegetable waste was collected randomly from traditional markets in Yogyakarta, ID.

\section{Work Procedures}

\section{Substrates preparation and sterilization}

Used cardboard and vegetable waste used as main substrates in eleven media compositions. Used cardboard was saturated in water for $48 \mathrm{~h}$ then drained from exceed water, while vegetable waste was composted for 7 days. Those main substrates were mixed with bioactivators, rice bran $(20 \%, \mathrm{w} / \mathrm{w})$ and $\mathrm{CaCO}_{3}$ $(2 \%, w / w)$ with the composition showed in Table 1. Eleven media compositions were sterilized using an autoclave at $121^{\circ} \mathrm{C}$ for $1 \mathrm{~h}$. The sterilized growing media was cooled for \pm $12 \mathrm{~h}$, then inoculated with the F3 of $P$. ostreatus seeds (Owaid et al., 2015; Sharma \& Madan, 1993).

\section{Cultivation and yield performance}

Incubated growing media was carried out until the mycelium filled it out completely and turned the media into white color and the mycelium growth a fruit body. Temperature was controlled between $22-25^{\circ} \mathrm{C}$ during the growing time for mycelium (Ahmed et al., 2013) and between $17-20^{\circ} \mathrm{C}$ for fruit body formation. Environmental humidity for mycelium growth and fruit body formation was controlled between $60-75 \%$ and $85-97 \%$, respectively (Chang \& Philip, 2004; Li et al., 2015). During the process, mushroom house was sprayed and aerated twice a day until the fruit bodies were ready to be harvested.

The parameters measured and observed included the physical and chemical properties of the media (temp., moisture content, $\mathrm{pH}$, and $\mathrm{C} / \mathrm{N})$, physical environmental conditions (temp. and $\mathrm{RH}$ ) and the production of $P$. ostreatus (total yield and biological efficiency). The biological efficiency (BE) is calculated by the formula (Singh \& Singh, 2012):

$$
\mathrm{BE}=\frac{\text { Fresh weight of mushrooms per bag }}{\text { Dry weight of substrate per bag }} \times 100 \%
$$

\section{Statistical analysis}

All statistical analyses were performed using SPSS software version for windows (IBM Corp, New York, USA). Completely randomized design (CRD) method with OneWay ANOVA was used to analyze the effect of variations in media composition on mushroom production results. Simple linear regression was used to determine the correlation between media and environment conditions in mushroom production.

\section{Results and Discussion}

In this research, the variations of media compositions produce different physicalchemical conditions, especially the condition of moisture content and $\mathrm{C} / \mathrm{N}$ value of the media. The moisture content in media composition I, II, III, IV, V, VI, and VII are quite high, ranging between $80-90 \%$ (Table 2), it showed that those media do not match with the recommended moisture content of the media to support mushroom growth (50-75\%) (Chang \& Philip, 2004). 
Table 1. Mushroom growing media composition

\begin{tabular}{lccc}
\hline \hline Composition & Code & Used Cardboard (\%) & Vegetable Waste (\%) \\
\hline \hline I & S & 0 & 100 \\
II & K1S9 & 10 & 90 \\
III & K2S8 & 20 & 80 \\
IV & K3S7 & 30 & 70 \\
V & K4S6 & 40 & 60 \\
VI & K5S5 & 50 & 50 \\
VII & K6S4 & 60 & 40 \\
VIII & K7S3 & 70 & 30 \\
IX & K8S2 & 80 & 20 \\
X & K9S1 & 90 & 10 \\
XI & K & 100 & 0 \\
\hline \hline
\end{tabular}

(*) Each composition consists of six replications with addition of $20 \%$ rice bran and $2 \% \mathrm{CaCO}_{3}$ by weight of the substrate.

(*) Each composition consists of six replications with addition of $20 \%$ rice bran and $2 \% \mathrm{CaCO}_{3}$ by weight of the substrate.

(*) $\mathrm{K}$ : used carboard, S : vegetable waste.

Table 2. Physical and chemical conditions of control and treatment media

\begin{tabular}{lccccccc}
\hline $\begin{array}{l}\text { Media Composition (\%) } \\
\text { Cardboard : Vegetable }\end{array}$ & $\mathbf{p H}$ & $\begin{array}{c}\text { Temperature } \\
(\mathbf{}\end{array}$ & & $\begin{array}{c}\text { Moisture } \\
\text { Content } \\
(\boldsymbol{\%})\end{array}$ & $\begin{array}{c}\mathbf{C} \\
(\boldsymbol{\%})\end{array}$ & $\begin{array}{c}\mathbf{N} \\
(\boldsymbol{\%})\end{array}$ & $\begin{array}{c}\mathbf{C} / \mathbf{N} \\
(\boldsymbol{\%})\end{array}$ \\
\hline \hline I & $0: 100$ & 7.0 & 25 & 90 & 35,81 & 1,40 & 25,58 \\
II & $10: 90$ & 7.0 & 25 & 90 & 36,08 & 1,30 & 27,75 \\
III & $20: 80$ & 7.0 & 24 & 85 & 36,69 & 1,06 & 34,61 \\
IV & $30: 70$ & 7.0 & 25 & 80 & 33,91 & 1,12 & 30,28 \\
V & $40: 60$ & 7.0 & 24 & 80 & 36,53 & 1,23 & 29,70 \\
VI & $50: 50$ & 6.9 & 23 & 80 & 37,86 & 0,95 & 39,85 \\
VII & $60: 40$ & 6.8 & 24 & 90 & 37,89 & 0,49 & 77,33 \\
VIII & $70: 30$ & 7.0 & 24 & 60 & 37,88 & 0,58 & 65,31 \\
IX & $80: 20$ & 6.8 & 23 & 70 & 36,43 & 0,80 & 45,54 \\
X & $90: 10$ & 7.0 & 23 & 60 & 38,43 & 0,58 & 66,26 \\
XI & $100: 0$ & 7.0 & 23 & 60 & 38,23 & 0,48 & 79,65 \\
Control & $0: 0$ & 7.0 & 23 & 70 & 39,40 & 0,45 & 87,56 \\
\hline \hline
\end{tabular}

The high moisture content in the seven media compositions are probably because of the high concentration of market vegetable waste mixed in the growing media, which is 40-100\% (w/w). Dewilda \& Darfyolanda (2017) showed that the more market waste is used, the higher the water content obtained in the media. In this study, vegetable market waste treated by composting in semi-anaerobic condition for a week with the addition of Effective Microorganism 4 (EM-4) bioactivator. This treatment resulted to even higher moisture content obtained in the media compared to before composted. Although in the process of making media (baglog) the moisture content is adjusted by $70 \%$, but the sterilization process contributed in the increase of the moisture content of the media, so the more vegetable compost added produce an increasing of moisture content up to $90 \%$. Media that have suitable moisture content to support the maximum growth of most mushroom are composition VIII-XI, which are $60-70 \%$. The variation of media composition also affected the $\mathrm{C} / \mathrm{N}$ value of the media. Media composition VIII-XI in this study produce $\mathrm{C} / \mathrm{N}$ in the range 45.54-79.65 that are close to the optimal $\mathrm{C} / \mathrm{N}$ for the growth of oyster mushrooms according to the research study of Tzeng (1974). These results showed that the higher concentration of cardboard (70$100 \%$ ) in the growing media makes the higher $\mathrm{C} / \mathrm{N}$ value of the media close to the optimal $\mathrm{C} / \mathrm{N}$ for the growth of oyster mushrooms. This result was comparable with the study of Tzeng (1974) in laboratory tests up to 60-80. 
Although the moisture content and $\mathrm{C} / \mathrm{N}$ of the various media compositions are quite diverse, the temperature $\left(23-25^{\circ} \mathrm{C}\right)$ and $\mathrm{pH}(6.8-7.0)$ of each media did not differ much (Table 2). The temperature and $\mathrm{pH}$ of the media in this study are in accordance with the conditions needed for mycelium growth stage, according to Ahmed et al. (2013) and Kalmis et al. (2008).

Table 3. Effect of media composition on mushroom production based on mycelium growth rate, total yield, and biological efficiency (BE)

\begin{tabular}{|c|c|c|c|c|}
\hline \multicolumn{2}{|c|}{$\begin{array}{l}\text { Media Composition (\%) } \\
\text { Cardboard : Vegetable }\end{array}$} & \multirow{2}{*}{$\begin{array}{c}\begin{array}{c}\text { Mycelium Growth } \\
\text { Rate (cm/day) }\end{array} \\
0 \pm 0.000^{\mathrm{a}}\end{array}$} & \multirow{2}{*}{$\frac{\text { Total Yield (gram) }}{0 \pm 0.000^{\mathrm{a}}}$} & \multirow{2}{*}{$\begin{array}{c}\begin{array}{c}\text { Biological Efficiency } \\
(\%)\end{array} \\
0 \pm 0.000^{\mathrm{a}}\end{array}$} \\
\hline I - VII & $0-60: 100-40$ & & & \\
\hline VIII & $70: 30$ & $1,28 \pm 0.166^{\mathrm{b}}$ & $72,07 \pm 12.331^{\mathrm{b}}$ & $31.39 \pm 5.535^{b}$ \\
\hline IX & $80: 20$ & $2,23 \pm 0.052^{c}$ & $93,71 \pm 11.226^{\mathrm{c}}$ & $45,38 \pm 8.088^{c}$ \\
\hline $\mathrm{X}$ & $90: 10$ & $2,22 \pm 0.113^{c}$ & $97,28 \pm 14.815^{\mathrm{c}}$ & $41,62 \pm 6.172^{c}$ \\
\hline XI & $100: 0$ & $3,91 \pm 0.166^{\mathrm{e}}$ & $96,69 \pm 8.990^{c}$ & $40,22 \pm 3.665^{c}$ \\
\hline Kontrol & $0: 0$ & $3,38 \pm 0.436^{\mathrm{d}}$ & $107,66 \pm 11.605^{\mathrm{c}}$ & $63,82 \pm 8.796^{\mathrm{d}}$ \\
\hline
\end{tabular}

Note: Numbers with one of the same letters show that the results are not significantly different based on the ANOVA test with a level of $5 \%$.

Based on the ANOVA test results (Table 3 ), it can be seen that the production of $P$. ostreatus in some media have significant differences, means that the variation of the growing media used showed significant influence on the production. In this study, about 30 days after the mycelium had grown to fill the media completely, the production of $P$. ostreatus (total yield) only found in the media composition VIII-XI and the positive control media (Figure 1).

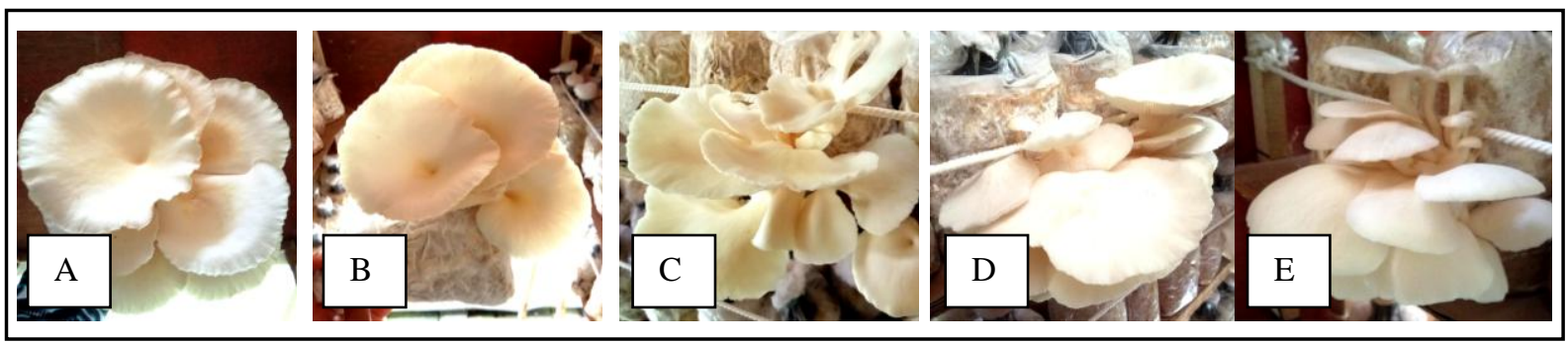

Figure 1. Fruiting bodies of $P$. ostreatus ready for harvest on media composition: A) VIII (70\% cardboard + $30 \%$ vegetable compost); B) IX (80\% cardboard + 20\% vegetable compost); C) X (90\% cardboard + $10 \%$ vegetable compost); D) XI (100\% cardboard + $0 \%$ vegetable compost); E) control positive (100\% sawdust).

The media composition IX-XI are the media that can produce maximum mycelium growth, maximum total yield, and maximum biological efficiency (BE) (Table 3). Media composition IX-XI can produce maximum production as shown in Table 3 and Figure 1 because of physical-chemical condition of the media that are adequate for the growth of $P$. ostreatus as previously discussed. The adequate media condition is caused by the high concentration of cardboard (80-100\%) and followed by the low concentration of vegetable compost in the growing media which ultimately creates media conditions that suitable for $P$. ostreatus growth, including the media sufficient density (Steviani, 2011).
Cardboard is also comes from wood, so the cardboard has the similar content as sawdust, which is rich in cellulose and lignin, then the higher cardboard concentration in the media will make the carbohydrate content in it will be higher too, especially cellulose and lignin as a carbon source. Finally the C-organic value as an energy source becomes high and is directly proportional to the $\mathrm{C} / \mathrm{N}$ in the media composition VIII-XI (especially media IX-XI) and is in accordance with the study of Tzeng (1974). The addition of vegetable compost with a maximum concentration only $10-30 \%$ can also supply nutrients such as sufficient nitrogen (not too high and not too low), vitamins, minerals, and based on the results of 
proximate analysis done by Muktiani et al. (2007) traditional market vegetable waste also still contains crude protein and crude fiber that can support the growth of oyster mushrooms. The higher cardboard concentration makes it possible to produce a better level of media density (not too dense and not too soft), which means the cavities or pores formed for mycelium can penetrate and spread quickly to fill the entire surface of the media getting bigger and more, so the number of primordia that can be formed and grow into maximum fruit bodies to be harvested is found from media composition IX-XI. The level of media density in this study is also a response to the value of moisture content in the media, because according to Patel et al. (2009) an increase in water content is believed to reduce porosity of the substrate, thereby limiting the transfer of oxygen to the entire surface of the media and finally can lead to failure of mycelium growth.

Table 4. Relationship of the physical-chemical condition of media to the mushroom production based on mycelium growth rate, total yield, and biological efficiency (BE)

\begin{tabular}{lccc}
\hline \hline Media Condition & Production Parameters & $\begin{array}{c}\text { Correlation } \\
\text { Coefficient }\end{array}$ & R square \\
\hline \hline \multirow{2}{*}{$\mathrm{pH}$} & Mycelium(cm/day) & 0,075 & 0,006 \\
& Total yield (gram) & 0,017 & 0,000 \\
& Biological efficiency $(\%)$ & 0,009 & 0,000 \\
Temperature $\left({ }^{\circ} \mathrm{C}\right)$ & Mycelium(cm/day) & $-0,704$ & 0,495 \\
& Total yield (gram) & $-0,709$ & 0,502 \\
Moisture Content $(\%)$ & Biological efficiency $(\%)$ & $-0,698$ & 0,487 \\
& Mycelium(cm/day) & $-0,802$ & 0,644 \\
& Total yield (gram) & $-0,875$ & 0,765 \\
$\mathrm{C} / \mathrm{N}$ & Biological efficiency $(\%)$ & $-0,803$ & 0,644 \\
& Mycelium(cm/day) & 0,746 & 0,556 \\
\hline \hline
\end{tabular}

The physical-chemical media condition that created by variations in media composition indirectly related to mushroom cultivation production is proofed by the results of a simple linear regression test. Based on the results of the regression test, the condition of the media which greatly influences the mycelium growth rate, total yield, and $\mathrm{BE}$ values are moisture content and $\mathrm{C} / \mathrm{N}$ value (Table 4). According to the table of interpretation of the correlation coefficient of the R value by Akdon in Kirom (2015), the correlation value between the moisture content of the media and the mushroom production shows a "very strong" relationship level, while the correlation value between the $\mathrm{C} / \mathrm{N}$ media with the mushroom production shows a "strong" relationships level. This indicates that the moisture content of the media has a greater influence than the $\mathrm{C} / \mathrm{N}$ of the media, as evidenced by the value of $\mathrm{R}^{2}$ or the coefficient of determination resulting from this simple linear regression test.

The production of $P$. ostreatus in this study were influenced by the media moisture content of $0.644-0.765(64.4-76.5 \%)$ and the
$\mathrm{C} / \mathrm{N}$ media only affected $0.513-0.556$ (51.3$55.6 \%$ ) (Table 4). Moisture content has a greater influence because the value of the moisture content of the media can produce more than one impact on the growth process of oyster mushrooms, including the impact on porosity of the substrate that associated with oxygen supply (Patel et al., 2009), the process of mycelium respiration (Urben, 2004), the distribution of nutrients from the mycelium to the fruit body (Oei \& Nieuwenhuijzen, 2005), and the metabolism of microbes or the development of undesirable microorganisms in mushroom cultivation (Urben, 2004). Different from the moisture content, the impact that can be caused by the $\mathrm{C} / \mathrm{N}$ media on the growth process of oyster mushrooms is smaller or less if the $\mathrm{C} / \mathrm{N}$ media is not in accordance with the optimal $\mathrm{C} / \mathrm{N}$. The $\mathrm{C} / \mathrm{N}$ value in a media represents the amount of nutrients present in the media, and it amount must be sufficient, according to Yang et al. (2013), higher or lower amount of nutrients in a media will inhibit the growth of mycelium or the fruit body formation. A strong level of relationship is also created between the media temperature 
with the mushrooms production, temperature has a less impact than the impact that can be caused by moisture content. It only impacted the enzyme activity in cells in the growth process of oyster mushrooms (Fujian, Hongzhang \& Zuohu, 2001).

Table 5. Relationship of environmental conditions to mushroom production based on mycelium growth rate, total yield, and biological efficiency (BE)

\begin{tabular}{lccc}
\hline \hline $\begin{array}{l}\text { Environmental } \\
\text { Conditions }\end{array}$ & Production Parameters & $\begin{array}{c}\text { Correlation } \\
\text { Coefficient }\end{array}$ & R square \\
\hline \hline & Mycelium(cm/day) & 0,799 & 0,639 \\
Temperature $\left({ }^{\circ} \mathrm{C}\right)$ & Total yield (gram) & 0,977 & 0,954 \\
& Biological efficiency $(\%)$ & 0,939 & 0,882 \\
& Mycelium $(\mathrm{cm} /$ day) & 0,994 & 0,988 \\
Humidity $(\%)$ & Total yield (gram) & 0,997 & 0,993 \\
& Biological efficiency (\%) & 0,985 & 0,970 \\
\hline \hline
\end{tabular}

Aside from media conditions, environmental conditions also determine the results of mushroom production in this study, because it affected each stage of mushroom growth. Based on the correlation values that are matched with the interpretation table of the correlation coefficient of $\mathrm{R}$ values by Akdon in Kirom (2015), the environment condition of the mushroom house has a "very strong" relationship with the mushroom production. Environmental conditions have great influences on production results, amounting to 0.639-0.954 (63.9-95.4\%) mushroom production are influenced by environmental temperature and 0.970-0.993 (97.0-99.3\%) were influenced by environmental humidity (Table 5).

The influence of the environmental conditions is greater than the influence of the physical-chemical condition of the media during the cultivation process, it can happen because the environmental conditions are not same every day. Different from the media condition that can be conditioned in such a way at the beginning of cultivation (on the beginning of making media) until towards the end of the cultivation process, environmental conditions always fluctuate following the weather at that time and more difficult to control during the summer (when this cultivation process is running), so that the total yield obtained in this study (Table 3) is actually not as expected, as well as the BE value. According to Khan et al. (2008), environmental factors such as temperature and humidity are very important for the production of oyster mushrooms.

The total yield and $\mathrm{BE}$ value that were not suitable with the expectations of this study were also the result of the low harvest frequency during the cultivation process, which only reached one period harvest in 4 months. It caused by unfavorable environmental conditions (difficult to control) during the cultivation process in the summer, finally changing mycelium conditions after the first harvest. Changes in mycelium conditions day by day are evidenced by the results of the first post-harvest observations showed in Figure 2.

From Figure 2(a-e) it can be seen that the mycelium condition in the second month after the first harvest has changed and looks different from the mycelium condition in Figure 2 (f), where Figure 2(f) is a condition of mycelium that is still fresh, shown with fibers such as fine white thread. The failure of primordial formation in the second period was caused by changes in the condition of the mycelium as seen in Figure 2(a-e) above. It can be seen that the mycelium in each media is still white but has begun to thin out, clumps together, and dries up, so that it cannot spread evenly to all parts of the media or baglog, finally the mycelium that is still there cannot grow into primordial back.

Changes in mycelium conditions are triggered by the environmental conditions of the mushroom house which are highly influenced by the weather so that it does not support the development of mycelium into fruit bodies. The conditions required for mycelium to grow up into fruiting bodies are temperature in the range of $17-20^{\circ} \mathrm{C}$ (Dahmardeh, 2013) and humidity that reaches 85-97\% (Chang \& Philip, 2004; Li et al., 2015), but in this study the temperature range in the mushroom house during the cultivation 
process reached $27-34^{\circ} \mathrm{C}$ and the humidity only reached $50-60 \%$ per day. This high temperature condition with low humidity causes the mushroom mycelium and primordial dries up, resulting in cessation of mushroom growth or mushroom death and unable to reach the next harvest period. This result is supported by Cahyana et al. (2001) which states that if the environmental temperature is too high followed by too low an environmental humidity, the primordial will dry out and die, therefore setting the temperature and humidity of the environment during the incubation until the harvest period is very important for the survival of the mushroom.

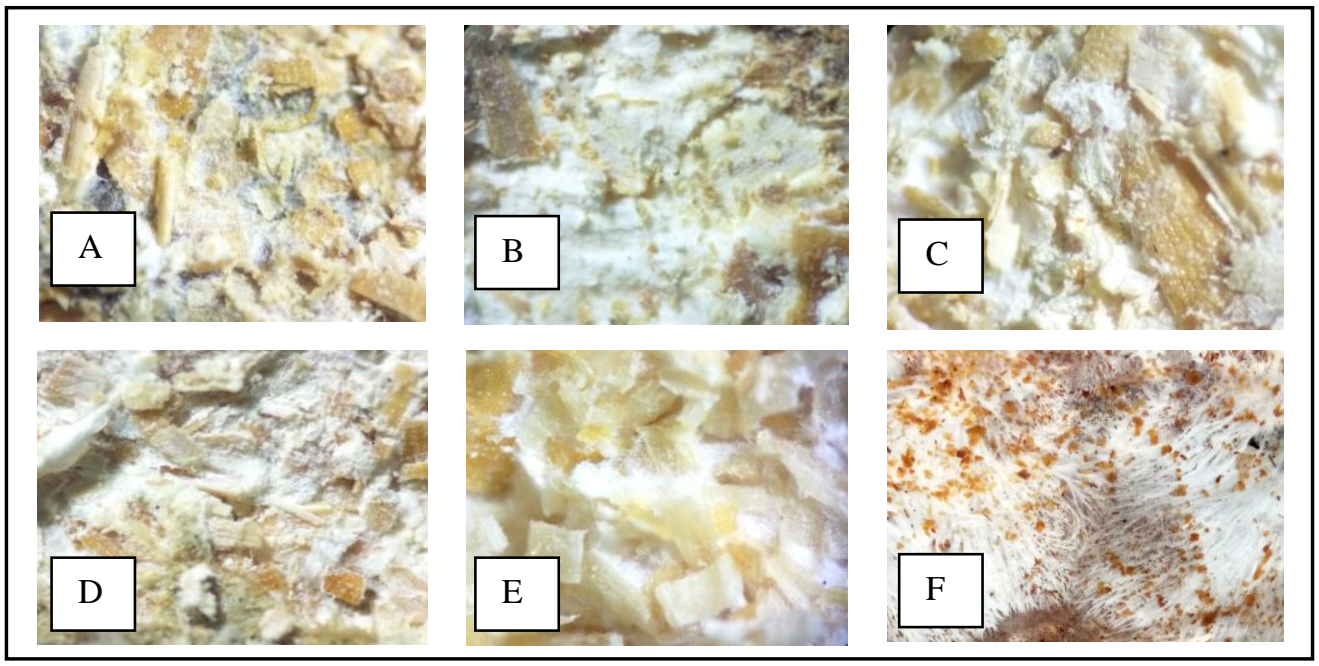

Figure 2. The condition of the first post-harvest mycelium on the media composition (observed with a stereo microscope on a scale of 10): A) VIII (70\% cardboard + 30\% vegetable compost); B) IX (80\% cardboard + $20 \%$ vegetable compost $)$; C) X (90\% cardboard + $10 \%$ vegetable compost); D) XI (100\% cardboard + $0 \%$ vegetable compost); E) control positive (100\% sawdust); F) fresh mycelium.

Based on the results of this study it can be seen that the condition of the media (especially temperature, moisture content, and $\mathrm{C} / \mathrm{N}$ value) has a strong and even very strong influence on the $P$. ostreatus production, therefore the accuracy of the media composition in mushroom cultivation is very important to be able to produce good media conditions that suitable for mushroom growth, so that the growth rate of mycelium, total yield, and the $\mathrm{BE}$ value reaches the optimum results. However, the accuracy of the media composition during the mushroom cultivation process must also be balanced with a conducive environmental conditions that support and in accordance with the conditions required at each stage of mushroom growth to be able to produce optimum and sustainable mycelium growth, so that the number of primordial produced to become fruit bodies ready to be harvested at each period is higher, and finally the production obtained (total yield and $\mathrm{BE}$ value) is higher. According to Qiu et al. (2017), environmental conditions is an important factor during the mycelium growth process to become a fruiting body. Three factors that must be considered in order to cultivate the mushroom successfully, such as seed quality, good substrate, and a conducive environment (Rajapakse et al., 2007).

\section{Conclusion}

The use of used cardboard with the addition of vegetable compost can be an alternative growth substrate for $P$. ostreatus in urban areas, with a maximum concentration of vegetable compost no more than $30 \%(\mathrm{w} / \mathrm{w})$. The media that is able to produce the maximum productivity is media composition XI $(100 \%$ cardboard $)$ with maximum mycelium growth rate up to $3.91 \mathrm{~cm} /$ day, media composition IX (80\% cardboard $+20 \%$ vegetable compost) with the best biological efficiency up to $45.38 \%$, and media composition X (90\% cardboard $+10 \%$ vegetable compost) with the highest total yield up to 97.28 grams. 


\section{References}

Ahmed, M. et al. (2013). Yield and Nutritional Composition of Oyster Mushroom Strains Newly Introduced in Bangladesh. Pesquisa Agropecuaria Brasileira, 48(2), pp. 197 202 doi: 10.1590/S0100204X2013000200010.

Cahyana, Y. A., Muchroji, M. Bakrun. (2001). Jamur Tiram. Penebar Swadaya, Jakarta.

Chang, S. T. \& Philip G. Miles. (2004). Mushrooms: Cultivation, Nutritional Value, Medicinal Effect, and Environmental Impact $2^{\text {nd }}$ Edition. CRC Press, New York, USA.

Dewilda, Y. \& F. L. Darfyolanda. (2017). Pengaruh Komposisi Bahan Baku Kompos (Sampah Organik Pasar, Ampas Tahu, dan Rumen Sapi) Terhadap Kualitas dan Kuantitas Kompos. Jurnal Teknik Lingkungan UNAND, 14(1):52-61.

Dahmardeh, M. (2013). Use of Oyster Mushroom (Pleurotus ostreatus) Grown on Different Substrates (Wheat and Barley Straw) and Supplemented at Various Levels of Spawn to Change the Nutritional Quality Forage. International Journal of Agriculture and Forestry, 3(4), pp. 138-140. doi: 10.5923/j.ijaf.20130304.02.

Fujian, X., Hongzhang, C. and Zuohu, L. (2001). Solid-State Production of Lignin Peroxidase (LiP) and Manganese Peroxidase (MnP) by Phanerochaete chrysosporium Using SteamExploded Straw as Substrate. Bioresource Technology, 80(2), pp. 149-151. doi: 10.1016/S0960-8524(01)00082-7.

Hakiki, A. et al. (2013). Pengaruh Tongkol Jagung sebagai Media Pertumbuhan Terhadap Kualitas Jamur Tiram (Pleurotus ostreatus). Jurnal Sains Dan Seni Pomits, 1(1), pp. 1-4.

Hariadi, Nurul, Lilik Setyobudi, Nihayati Ellis. (2013). Studi Pertumbuhan dan Hasil Produksi Jamur Tiram Putih (Pleorotus ostreatus) pada Media Tumbuh Jerami Padi dan Serbuk Gergaji. Jurnal Produksi Tanaman, 1(1), 47-53.

Kadam, R. M., Patil, S. S. and Jadhav, B. S. (2008). Production of Protein by Fungi, Pleurotus Species from Different Agricultural Wastes. International Journal of Plant Protection, 1(2), pp. 45-47.

Kalmis, E. et al. (2008). Feasibility of Using Olive Mill Effluent (OME) as A Wetting Agent During the Cultivation of Oyster Mushroom, Pleurotus ostreatus, on Wheat Straw.
Bioresource Technology, 99(1), pp. 164169. doi: 10.1016/j.biortech.2006.11.042.

Khan, M. A., Amin S. M. R., Uddin M. N., Tania M., Alam N. (2008). Comparative Study of the Nutritional Composition of Oyster Mushrooms Cultivated in Bangladesh. Bangladesh J Mushroom. 2: 9-14.

Kirom, B. (2015). Mengukur Kinerja Pelayanan dan Kepuasan Konsumen. Pustaka Reka Cipta, Bandung.

Kulshreshtha, Shweta et al. (2013). Cultivation of Pleurotus citrinopileatus on Handmade Paper and Cardboard Industrial Wastes. Industrial Crops and Products. Elsevier B.V., 41(1), pp. 340-346. doi: 10.1016/j.indcrop.2012.04.053.

Li, W. et al. (2015). Effects of Different Carbon Sources and $\mathrm{C} / \mathrm{N}$ Values on Nonvolatile Taste Components of Pleurotus eryngii. International Journal of Food Science and Technology, 50(11), pp. 2360-2366. doi: 10.1111/ijfs.12901.

Mandeel, Q. A., Al-Laith, A. A. and Mohamed, S. A. (2005). Cultivation of Oyster Mushrooms (Pleurotus spp.) on Various Lignocellulosic Wastes. World Journal of Microbiology and Biotechnology, 21(4), pp. 601-607. doi: 10.1007/s11274-004-3494-4.

Muktiani, A., Tampoebolon, B. and Achmadi, J. (2007). The In Vitro Rumen Fermentability on the Processed Vegetable Waste. Journal of the Indonesian Tropical Animal Agriculture, 32(1), pp. 44-50.

Oei, P., \& Nieuwenhuijzen, B.V. (2005). Smallscale Mushroom Cultivation: Oyster, Shiitake, and Wood Ear Mushrooms. Agromisa Foundation and CTA, Wageningen.

Owaid, M. N., Abed, A. M. and Nassar, B. M. (2015). Recycling Cardboard Wastes to Produce Blue Oyster Mushroom Pleurotus ostreatus in Iraq. Emirates Journal of Food and Agriculture, 27(7), pp. 537-541. doi: 10.9755/ejfa.2015.04.118.

Patel, H., Gupte, A. and Gupte, S. (2009). Effect of Different Culture Conditions and Inducers on Production of Laccase by a Basidiomycete Fungal Isolate Pleurotus ostreatus HP-1 Under Solid State Fermentation. BioResources, 4(1), pp. 268284. doi: 10.15376/biores.4.1.268-284.

Qiu, Z. et al. (2017). High Temperature Enhances the Ability of Trichoderma asperellum to Infect Pleurotus ostreatus Mycelia. PLoS 
ONE, 12(10), pp. 1-16. doi: 10.1371/journal.pone.0187055.

Rajapakse, J. C., Rubasingha P., Dissanayake N. N. (2007). The Potential of Using CostEffective Compost Mixtures for Oyster Mushroom (Pleurotus species) Cultivation in Sri Lanka. Tropical Agricultural Research and Extension. 10: 29-32.

Sharma, S. and Madan, M. (1993). Microbial Protein from Leguminous and Non-Leguminous Substrates. Acta Biotechnologica, 13(2), pp. 131-139. doi: 10.1002/abio.370130210.

Singh, M. P. and Singh, V. K. (2012). Biodegradation of Vegetable and Agrowastes by Pleurotus sapidus: A Novel Strategy to Produce Mushroom with Enhanced Yield and Nutrition. Cellular and Molecular Biology, 58(1), pp. 1-7. doi: 10.1170/T913.

Singh, V. K. and Singh, M. P. (2014). Bioremediation of Vegetable and Agrowastes by Pleurotus ostreatus: A Novel Strategy to Produce Edible Mushroom with Enhanced Yield and Nutrition. Cellular and Molecular Biology, 60(5), pp. 2-6. doi: 10.14715/cmb/2014.60.5.2.
Stamets, P. and Chilton, J. S. (1983). The Mushroom Cultivator: A Practical Guide to Growing Mushrooms at Home, S. Cal. L. Rev. doi: 10.1002/mus.23999.

Steviani, Susi. (2011). Pengaruh Penambahan Molase dalam Berbagai Media Pada Jamur Tiram (Pleurotus ostreatus) [Skripsi]. Fakultas Pertanian, Universitas Sebelas Maret, Surakarta. [Indonesia].

Tzeng, D. S. (1974). Studies on Nutritional Requirements and the Improvement of Techniques in Cultivation of Straw Mushroom Volvariella volvariella (Bull. Ex Fr.) Sing. [M.Sci. Thesis]. Taichung [Taiwan]: National Chung Hsing University

Urben, A.F. 2004. Produca o de Cogumelos por Meio de Tecnologia Chinesa Modificada. Embrapa Recursos Gene'ticos e Biotecnologia, Brası'lia (in Portuguese).

Yang, W. J., Guo, F. L. and Wan, Z. J. (2013). Yield and Size of Oyster Mushroom Grown on Rice/Wheat Straw Basal Substrate Supplemented with Cotton Seed Hull Saudi Journal of Biological Sciences. King Saud University, 20(4), pp. 333-338. doi: 10.1016/j.sjbs.2013.02.006. 